\title{
Distribution of Depositors' Return and The Income Smoothing Hypothesis by Malaysian Islamic Banks
}

\author{
Zunaidah Sulong (Corresponding author) \\ Faculty of Economics and Management Sciences, Universiti Sultan Zainal Abidin, \\ 21300 Terengganu, Malaysia \\ Tel: +609-6688253 Email: zunaidah@unisza.edu.my \\ Nurul Syazwani Mohd Noor \\ Institute of Islam Hadhari, Universiti Kebangsaan Malaysia, \\ 43600 Bangi, Selangor \\ Tel: +609-6688253 Email: waniesyaz@gmail.com
}

\begin{abstract}
The paper aims to examine whether Malaysian Islamic banks carry out income smoothing with regards to their distribution of depositors' return. The paper also examines the extent Malaysian Islamic banks engage earnings and capital management in their distribution of depositors' return. This empirical study uses balanced panel data from 16 Malaysian Islamic banks, for the period 2008-2012. The regression model is estimated using random effects specifications. The findings indicate that the earnings before tax, zakat, and provision have a positive but insignificant effect on distribution of depositors' return (DDR) whilst the total capital before provision has a positive and significant effect on the DDR. These findings suggest that Islamic banks carry out income smoothing on the distribution of depositors' return via capital management. Islamic banks also smooth their earnings through distribution of depositors' return to avoid earnings troughs when earnings are poor. The findings shows prudence exercise among Malaysian Islamic banks with the objectives of mitigating displaced commercial risk (DCR), which involves massive withdrawal and bank runs risks.
\end{abstract}

Keywords: Income smoothing; Distribution of depositors' return (DDR); Islamic banks; Investment account holders (IAHs); Displaced commercial risk (DCR)

\section{Introduction}

Despite the heightened global economic uncertainty, the Islamic banking industry remains resilient, recording steady growth. Table 1 shows the size and year-on-year (YOY) growth of global Islamic banking and Islamic fund sectors' assets (Haneef, 2015; Zunaidah, 2015). The growth is well supported since 10 out of 25 Rapid-Growth Markets (RGMs) are largely populated by Muslims (World Islamic Banking Competitiveness Report 2013-2014). The trend demonstrates trust in the Islamic banking industry as it displays more sustainable growth and emphasizes on issues that require strong and sustained policies and a more sophisticated regulatory framework without sacrificing innovation. 
GJAT | JANUARY 2018 | SPECIAL ISSUE $\mid 172$

ISSN : 2232-0474 | E-ISSN : 2232-0482

www.gjat.my

Table 1: Size and year-on-year increase of global Islamic banking assets and Islamic funds

\begin{tabular}{|l|l|l|l|l|l|}
\hline \multirow{2}{*}{ Period } & \multirow{2}{*}{ Year-on-Year (YOY) } & Islamic Banking Assets & Islamic Fund Assets \\
\cline { 3 - 6 } & Size (USD billion) & Changes (\%) & Size (USD billion) & Changes (\%) \\
\hline 2013 & $2012-2013$ & 778 & $13.91 \%$ & 73 & $8.93 \%$ \\
\hline 2012 & $2011-2012$ & 683 & $19.41 \%$ & 67 & $1.64 \%$ \\
\hline 2011 & $2010-2011$ & 572 & $16.73 \%$ & 62 & $8.06 \%$ \\
\hline 2010 & $2009-2010$ & 490 & $17.51 \%$ & 61 & $8.96 \%$ \\
\hline 2009 & & 417 & & 56 & \\
\hline
\end{tabular}

Source: Bloomberg, Eurekahedge, KFHR \& World Islamic Banking Competitiveness Report 2014-2015 (Adapted Haneef, 2015 and Sulong, 2015).

An expansion requires the Bank Negara Malaysia (BNM) to conduct a review on the Framework of the Rate of Return to further strengthen the formula used to derive the rate of return to depositors. The Islamic Financial Services Act 2013 has ensured distinct difference between Islamic investment accounts and Islamic deposits. The Bank Negara Malaysia (BNM) has released a policy document in 2014 on regulatory requirements of investment accounts (see, BNM 2014). This is in line with Core Principles for Islamic Finance Regulation (CPIFR) issued by the Islamic financial services industry (IFSI). The CPIFR facilitates assessment of the regulation and supervision of the Islamic banking sector (by self-assessments, peer reviews or other external assessments) thereby contributing to the promotion of a resilient and stable financial system. The new CPIFR 14 replaces the Basel Core Principles (BCPs) in providing guidelines with regards to profit sharing investment account / investment account holders (PSIA/IAHs). On the whole, the enactment of a number of new central bank acts in 2009 including the Central Banking Act 2009 (CBA), the Islamic Financial Services Act 2013 (IFSA) and the Financial Services Act 2013 (FSA) rounds up a series of comprehensive legislative reforms that has been undergone by the Malaysian banking industry. The revised framework provides a greater degree of flexibility and an effective regulatory guidelines to support the challenging industry environment.
Furthermore, Islamic bank's management are given the flexibility to use their distribution of depositors' return (DDR) as a mechanism

to stabilize and maintain the rate of return on mudharabah investment accounts as their income smoothing efforts. In certain situations, managers are given latitude in terms of accounting in order to determine the figure printed in the earnings report for a particular period (Gaganis et al., 2015). The income smoothing practice allows them to deliberately dampen earnings' fluctuations or lessen the variations in earnings over time (Albrecht \& Richardson, 1990; Saringat et al., 2013). Typically, it is a form of earnings management designed to remove peaks and troughs, thereby reducing volatility and bringing an impression of a more stable and less risky investment. Measures taken include reducing and "saving" profits during good years for use during not-sogood years (Ashour, 2011). The bank manager's ability to steadily manage earnings volatility create confidence in the market, as shown by the rather stable deposits and lack of massive withdrawals (Ismail et al., 2005).

It is an obligation for banks to distribute returns generated from depositors' funds (Mulyo, 2012). The distribution of profit takes the IAHs into account, with the IAHs profit distribution rate calculated as a function of distributions to IAHs divided by average IAHs funds for a specified period i.e. quarter, semi-annual or annual. Meanwhile, the profit distribution rate 
is calculated by dividing the total distributions paid to IAHs with the average IAHs funds over the period. A higher figure points to an increase in profit distribution management pattern.

Despite the extensive literature available on earnings management and income smoothing surrrounding conventional banking industries, those that investigate income smoothing practices by Islamic banks are still limited. Previous studies by Misman and Ahmad (2011), Taktak et al. (2010), Zoubi and AlKhazali (2007), Ismail and Be Lay (2002), and Ahmed et al. (1999) have all examined the use of loan loss provision (LLP) as earnings and capital management tool for income smoothing purposes in IFIs. In a more recent study, Md. Ramli et al. (2012) examined whether Islamic banks manage their earnings and capital using profit equalisation reserve (PER). Studies looking at earnings management as income smoothing instrument were also done recently by Farooq et al., (2012), and Faouzi and Zarai (2013) but none of them looked at distribution of depositors' return for such purpose. This paper, thus, aims to determine whether Malaysian Islamic banks manage their earnings and capital through distribution of depositors' return (DDR) by using Asset Spread measure.

\section{Literature Review}

\section{Islamic Banks' Characteristics and Operations.}

Islamic banks operate in a unique requirement in line with Shariah principles. Their governance which is in accordance to Shariah rules makes Islamic banks' operations differ from their conventional counterparts (Taktak et al., 2010; Md. Ramli et al., 2012). Islamic banks' products, financial instruments, operations and management processes must abide by the rules of Islamic law (Maqasid al Shariah). In Malaysia, the Islamic banks are governed by regulatory framework outlined by Bank Negara Malaysia (BNM) for Islamic financial institutions (IFIs).
Shariah particularly prohibits trading or investing in speculative activities (gharar), derivatives and non-permissible (haram) sectors and products. The Shariah principles also prohibit Islamic banks from paying or receiving interests (riba) in their financial and commercial transactions. This prohibition makes the banks' investment approach unique since they exclusively operate on profit and loss sharing (PLS) arrangements, which means that the banks share profits and losses with their customers. This PLS principles affect both sides of Islamic bank balance sheet; its assets and liabilities as they do investors, entrepreneurs (borrowers) and depositors (Chong \& Liu, 2009; Hamza \& Saadaoui, 2013). Figure 1 shows Islamic bank balance sheet structure based on contracts.

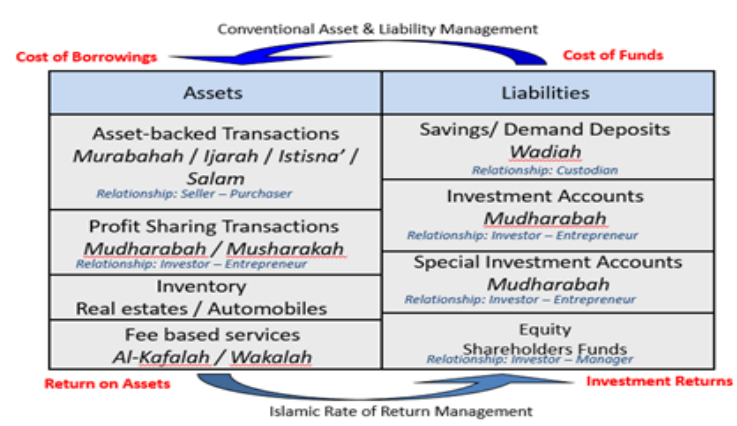

Figure 1: The Islamic bank balance sheet structure and contracts (Source: ISRA, 2013)

On the liabilities side, the principle of PLS is applied through profit sharing investment accounts (PSIA), a contractual relationship between Islamic banks and investment account holders (IAH), i.e. the PSIA holders, called Mudharabah contract. The contract assumes depositors a role of capital provider (rabbul $\mathrm{mal}$ ) and the bank the role of entrepreneur (mudharib). The depositors' funds are utilized in financing and investment activities, and the profits generated from these activities are shared between the depositors and the bank based on the pre-agreed profit sharing ratio. In case of a loss, the losses are borne by the IAHs. Nevertheless, losses due to misconduct and negligence are borne by the banks (operational risk) (Taktak et al., 2010; ISRA, 2012). Sundararajan (2015) 
recently worked on finding a methodology to estimate the "Displaced Commercial Risks (DCR)" shared by depositors (IAHs) with shareholders.

Besides Shariah principle, Islamic banks and conventional banks also differ substantially in their provisioning policy (Taktak et al., 2010; Md. Ramli et al., 2012). The Accounting and Auditing Organization for Islamic Financial Institutions (AAOIFI) encourages the use of dynamic provisioning by Islamic banks. This policy allows them to anticipate the risk of loan losses based on expected losses rather than the actual losses via loan loss provisions (LLPs). BNM, through its Islamic Financial Services Board (IFSB), also requires all Malaysian Islamic banks to allocate several reserves for profit and loss sharing products namely profit equalization reserve (PER) and investment risk reserve (IRR)(Md Ramli et al, 2012). Both mechanisms help reduce the volatility of rate of return from investment deposits hence smoothing their income. These protect Islamic banks from DCR as well as maintain their stability and competitiveness.

Previously in practice, Islamic banks use profit equalization reserve (PER) to smooth their income. PER is calculated based on the BNM Rate of Return (RoR) framework (Ismail, 2010). PER is deducted from return earned from investment prior to profit distribution to shareholders, the IAHs. However, there is no universal agreement among Islamic financial institutions regarding its calculation and use. So far, Islamic banks determines the formula at their own discretion (Ismail and Shahimi, 2006; Taktak et al., 2010; Farook et al., 2012). It should be noted that what needs to be stabilized is the profit payouts, not the profit itself and that PER is a reserve, not a provision. Meanwhile, IRR is the amount appropriated by the Islamic banks out of the income of IAH, after allocating the mudharib share, in order to cater against future losses for IAHs (Ismail, 2010). The aim of IRR is specifically to cover the whole or a part of potential losses on assets (Sundararajan, 2008).
Regarding capital regulation in Malaysia, the Committee on Banking Regulation and Supervisory Practices requires all banks to maintain a minimum capital of $8 \%$ from the banks' risk weighted assets (RWA) since the amendment of the capital adequacy framework in 1990. The amendment of the capital adequacy regulations may have affected the banks' ability to manage earnings and capital through LLPs (Ahmed et al., 1999) hence, the distribution of return to IAHs. In general, total capital consists of Tier I and II. Tier 1 capital is the sum of book value of equity, common stock plus noncumulative preferred stock and minority interest in the equity accounts of subsidiaries, less goodwill and other intangible assets (Md. Ramli et al., 2012). Tier II capital, on the other hand, is the sum of loan loss reserves (up to a maximum of $1.25 \%$ of RWA), perpetual preferred stock, hybrid capital instruments, perpetual debt, mandatory convertible debt securities, term subordinated debt and intermediate preferred stock. Tier I must exceed at least $4 \%$ of the RWA and 3\% of total assets, whilst the amount of Tier II must not exceed the amount in Tier I (Misman and Ahmad, 2011). On top of that, this framework requires a minimum of $50 \%$ of total capital be supplied by Tier I.

\section{Distribution of Depositors' Return (DDR) Measure}

DDR can be defined as profit allocation to different categories of recipients, for different purposes. Mulyo (2012) defined distribution of income as a product of a calculation of distribution relating to business venture between sahibul maal and mudharib according to a pre-agreed ratio. Islamic banks have the flexibility to adjust their profit distributions ex-post after taking into account the management fee attributable to both IAHs and shareholders. Whilst Islamic banks have an explicit contractual obligation to share profits with depositors (Farook et al., 2012), at the same time, they faces implicit pressure to provide competitive return that is at least similar to market based deposit interest rates (Sundararajan, 2008). 
Taking into account DDR's role in profit distribution management, several studies adopt DDR as a variable in measuring management of profit distribution. Farook and Farooq (2011) stated that there are two approaches to income smoothing: 1) period specific smoothing measure, which requires a triangular calculation of three different measures (IAH Profit Distribution Rate, Rate of Return on Financing Assets, Market Deposit Rate) and 2) cumulative period's measure, where the profit distribution rate is calculated by taking the total distributions paid to IAHs over the average IAHs funds over the period. However, these measures have some constraints in identifying IAHs Profit Distribution Rate for particular Islamic banks due to undisclosed information to explain the exact depositor profit distribution rate for each investment account.

In an earlier study, Sundararajan (2005) claimed that Islamic banks choose to provide their profit distribution similar to interest rates and not based on fundamental asset returns. One way to know for sure is to use a bank-year specific variable such as Asset Spread in our study. It is an absolute spread between return on assets (ROA), after considering all expenses, but excluding depositors' profits, and return on investment account holders (ROIAH) (Farook et al., 2012). Asset Spread is the most useful means of measuring profit distribution since it considers all revenues and expenses, and provides a spread between total asset return on the bank's asset, services portfolio and distributions paid to depositors.

In reference to the characteristic of Malaysian Islamic banks financial statement, the Asset Spread is calculated based on the spread between banks' revenues and expenses. It includes income from depositor and income from shareholder's fund (total revenues) minus allowance, provisions, direct expenses, PER, personnel expenses, and overhead expenses (total expenses). Farook et al (2012) have also suggested a second measurement called Deposit Spread, which is the absolute inverse of the spread between average competitive deposit rates for all banks for a particular year for a particular country and the average rate of distributed profits of a particular Islamic bank in that particular year. It helps determine the magnitude of profit distribution management towards the average deposit rate of the respective host country, with a larger inverse value indicating greater profit distribution management (Faouzi and Zarai, 2013).

Equity Spread is the third means of measure, defined as the absolute spread between the average return on equity (ROE) and the average rate of depositors' profits distributed. A higher absolute spread indicates a higher degree of profit distribution management (Faouzi and Zarai, 2013). The depositors' profit rate distributed is calculated by dividing the profits distributed by the total depositors' base, excluding current accounts, which are not entitled to profits. Nevertheless, a common limitation with this calculation method is the aggregation in the depositors' profit rates. There is no viable method in which the exact depositor profit distribution rate for each investment account can be deciphered. Furthermore, the depositor base may compose of highly differing proportion in each account. When such information is aggregated, the true rate of return on each deposit account type cannot be deciphered and only an aggregate rate can be deduced (Farook et al., 2012). This implies that the measure does not accurately capture the distribution rate paid to depositors.

Lastly, a combined measure of profit distribution management is an absolute number known as Combined Spread, which is the inverse of the Deposit Spread multiplied by the Asset Spread. A high Combined Spread implies a high degree of profit distribution management whereas a low Combined Spread implies limited or lack of profit distribution management. This produces a variable that increases with the extent of profit distribution management. However, this measure relies on the quality of the two underlying variables (Asset Spread 
and Deposit Spread), therefore, its accuracy is reflected by the accuracy of those two (Farook et al., 2012).

At country level, most of the studies on Islamic banks include a number of variables that take on the same value for all banks in a given country. This study, however, adjusts for the impact of macroeconomic cycle by including macroeconomic variables the likes of gross domestic product (GDP) growth rate and control variables i.e. non-performing financing, size of the bank, and age of the bank.

\section{Income smoothing Practice}

Barnea et al. (1976) defined income smoothing as a deliberate dampening of fluctuations about some level of earnings which is considered normal for the firm. In other words, income smoothing refers to an act of minimizing variations in earnings over time. Essentially, the extent of smoothing is the extent to which the banks return to unrestricted IAH, varies from its fundamental return on its assets, less any mudharib fees (Islamic Financial Services Board (IFSB), 2005). Income smoothing can be measured using two measures both of which involve IAHs profit distribution; period specific smoothing measure and cumulative periods' measure (Farook and Farooq, 2011). Eventhough the cumulative period's measure is preferred, the choice is still upon investigators' discretion and dependent of additional data from IFIs.

Unfortunately, past studies documenting income smoothing practice through management of return distribution by Islamic banks are limited compared to conventional banks. Ahmed et al. (1999) found strong evidence for LLP's use in capital management in 1990 upon changes in capital adequacy regulations. In 2002, Ismail and Be Lay (2002) found that Malaysian banks were using LLPs to manage their earnings during the period of 1997-1999. On the contrary, Ismail et al. (2005) found that Malaysian commercial banks offering dual products (Islamic and conventional) were not using LLPs in managing their earnings during the 1998-2001 period. Instead they used realized security gains and losses.

Where Spanish banks are concerned, LLPs were not used as a tool for managing capital after the new regulation came into effect. Instead, they adopted a more aggressive earnings management strategy (Anandarajan et al., 2003). In Australia, Anandarajan et al., (2006) found that earnings management behaviour is more pronounced in the post-Basel period, which was enforced for the first time in 1992. Zoubi and Al-Khazali (2007) also confirmed the use of income smoothing practice by forty-seven conventional and Islamic banks operating in the Gulf Cooperation Council (GCC) region over the period of 2002-2003.

For another smoothing technique, Ismail and Shahimi (2006) have provided evidence that Islamic banks in Malaysia used PER over the period 2002-2004 to smooth their results and stabilize returns to IAHs. The result shows that net non-performing financings, net income before provision, and capital ratio significantly determine the PER. Fonseca and Gonzalez (2007) have suggested a declining degree of income smoothing practices when investor protection, extent of accounting disclosure, restrictions on bank activities and official and private supervision are concerned, and an inclining ones when associated with marketorientation and development of the financial system.

Recently, Taktak et al. (2010) found that earnings management by Islamic banks across 19 countries from 2001 to 2006 did not use LLP. In 2011, Taktak went on to suggest that a large number of Islamic banks engage in natural income smoothing. This is based on the determination of coefficient which reported that 70 percent of banks were found to have less smoothed total revenue than their net income. In the Palestinian banking industry, bank managers use LLPs to meet the legal reserve requirements but use other means to smooth their incomes (Ashour, 2011). 
At one point, the earnings management is said to be insignificant to income smoothing. The result found by Md. Ramli et al. (2012) suggested that earnings management is not an important determinant of PER since the variable, earnings before tax, zakat, and provision (EBTZP), was insignificant in the context of managing earnings through PER. There are two steps to measuring earnings management in banks. First, LLP gets decomposed into nondiscretionary and discretionary components followed by the discretionary component being a proxy for earnings management. Decreasing the discretionary loan loss provision increases earnings and Tier 1 capital. Based on 712 bankyear observations for the period of 1994-2007, it was found that unlike non-regulated industries, managers' equity incentives and earnings management are not significantly correlated in the banking industry. This result implies that, generally, equity incentives does not affect earnings management (Cheng et al., 2011).

Farook and Farooq (2011) have proposed that prudential regulators require IFIs to hold more capital, based on the extent to which they smooth returns to their depositors. Most IFIs are currently required to hold only a certain percentage (between 30 and 100 percent) of their assets financed by IAHs against the required capital from its shareholders, without taking into account the degree of income smoothing the IFIs carry out. Having said that, supervisory authorities are naturally concerned with systemic risks associated with absence of income smoothing (IFSB, 2005; Taktak et al., 2010). Thus, a balance between the two, capital requirement and income smoothing, is pertinent to the health of the banking industry.

Farook et al., (2012) discovered that Islamic banks that manage profit distributions according to interest rates expose themselves to higher earnings volatility compared to those, conventional or Islamic, that do not. The results suggest that the extent of profit distribution management is inversely associated with financial stability. The banks that engage in substantial profit distribution management are likely to be less financially stable than their peers. As a result, Islamic banks that are heavily invested in fixed rate instruments and are engaged in managing profit distributions to depositors are exposed to higher fluctuations in their earnings. This is because they are exposed to returns mismatch due to fixed rate assets, on top of the usual discrepancies between asset and liability returns.

By using the Asset Spread measure on sixteen Malaysian Islamic banks, preliminary results by Mohd Noor and Sulong (2013) showed that earnings management and capital management have insignificant relation to profit distribution management to depositors. This suggests that Malaysian Islamic banks' reluctance to smooth their earnings through profit distribution management. The current study requires further refinement in terms of measurement proxies used and consideration for alternative measures involving established proxies namely profit distribution, capital, and earnings management for Malaysian Islamic banks.

Given the inconclusive findings of past studies and relatively few techniques used to measure smoothing activity, it would be interesting to examine empirically the nature of income smoothing practiced by Islamic banks through DDR besides the existing LLPs, IRR, and PER.

There are quite a number studies done on income smoothing techniques (for example, Ismail and Be Lay, 2002; Ahmed et al, 1999; Anandarajan et al., 2003; 2006; Ashour, 2011; Misman and Ahmad, 2011; Md. Ramli et al., 2012). However, studies that look at the use of distribution of depositors' return for the purpose of income smoothing is very limited and preliminary in nature. They include those by Sundararajan (2005), Farook et al., (2012), Faouzi and Zarai (2013), and Mohd Noor and Sulong (2013). Therefore, this study will use DDR as a dependent variable to investigate the relationship between DDR and earnings as well as capital management in Malaysian Islamic banks. The study specifies the following hypotheses: 
$\mathbf{H}_{1 \mathrm{a}} \quad$ There is a significant effect between earnings management (EBTZP) and distribution of depositors' return (DDR) concerning Malaysian Islamic banks.

$\mathbf{H}_{1 \mathrm{~b}} \quad$ Earnings management with interactive dummy negative earnings (EBTZP*DEM) has a positive relationship with distribution of depositors' return (DDR).

$\mathbf{H}_{2 \mathrm{a}} \quad$ There is a significant effect between capital management (TCBP) and distribution of depositors' return (DDR) concerning Malaysian Islamic banks.

$\mathbf{H}_{2 \mathrm{~b}} \quad$ Capital management with interactive dummy loan loss reserve (TCBP*DCM) has a positive relationship with distribution of depositors' return (DDR).

\section{Methodology}

\section{Sample and Data}

The study sample consists of eighty bankyear observations of sixteen Islamic banks; 2 full-fledged Islamic banks, 8 Islamic banking subsidiaries, and 6 foreign Islamic banks operating in Malaysia. It involves a balanced panel data for a 5-year period beginning 2008 and ending 2012 (refer Appendix A). The banking data obtained are from individually audited and published annual financial statement of Malaysian Islamic banks while the data concerning macroeconomic effect and control variables are obtained from BNM website.

\section{Variable measurement}

Distribution of Depositors' Return (DDR)

According to Farook et al. (2012), Asset Spread is the closest indicator of distribution of depositors' return measure. It takes into account all revenues and expenses and provides the spread between total asset return on the bank's assets, services portfolio, and distribution paid to depositors. Therefore, Asset Spread is chosen as distribution of depositors' return measure in this study to reflect the nature of standard Malaysian Islamic banks' financial statements. The distribution of depositors' returns (Asset Spread) can be derived from the difference between return on assets (ROA) and return on investment of account holders (ROIAH) as laid out in Equation (1).

$$
\text { DDR }=(\text { ROA })-(\text { ROIAH })
$$

Where,

$$
\begin{array}{ll}
\text { ROA } & =\text { Return on Assets } \\
\text { ROIAH } & =\begin{array}{l}
\text { Return on investment of } \\
\text { account holders }
\end{array}
\end{array}
$$

To test the use of DDR in income smoothing practices of Islamic banks, this study investigates the smoothing effects of variable EBTZP on earnings management. The group of banks' income smoothing is identified by using the coefficient from Ismail and Shaharuddin (2003), Taktak et al. (2010), Misman and Ahmad (2011), and Md. Ramli et al. (2012). Md Ramli et al (2012) recognized involvement of EBTZP in examining income smoothing practice in Malaysian banking industry. Banks reduce provision to have better EBTZP when earnings are low (Misman and Ahmad, 2011). Algebraically, EBTZP is expressed as follows:

$$
\text { Earnings management }=\sum_{i=1}^{n} f(\text { EBTZP })
$$


Where,

\begin{tabular}{|l|l|l|}
\hline EBTZP & $=$ & $\begin{array}{l}\text { earnings before } \\
\text { tax, zakat } \\
\text { and provision } \\
\text { normalized by } \\
\text { total assets } \\
\text { number of banks } \\
1,2,3 \ldots \mathrm{n}\end{array}$ \\
$\mathrm{i}$ & $=$ \\
\hline
\end{tabular}

\section{Capital Management.}

A total capital before provisions (TCBP) is measured by using primary capital or Tier 1 capital. This variable is able to identify banks with low capital or financial problems. Md. Ramli et al. (2012) included this variable in their study to test banks' capital management and found that total capital before provision (TCBP) is significantly affecting PER, thus, support the capital management hypothesis. The aim of including TCBP is to determine the existence of capital management behaviour in relation to loan loss reserves and capital requirement ratio. Beatty et al. (1995) examined the relationship between LLP and capital before the Basel I, and Taktak et al. (2010) and Misman and Ahmed (2011) looked at the effect of capital adequacy ratio on LLP. Total capital before provisions (TCBP) is calculated using information available in annual reports and capital management is a product of the following function:

Capital management $=\sum_{\mathrm{i}=1}^{\mathrm{n}} \mathrm{f}(\mathrm{TCBP})$

Whereby,

TCBP =total capital before provision, normalized by total assets

$\mathrm{i}=\quad$ number of banks $1,2,3 \ldots \mathrm{n}$

\section{Control Variables.}

Non-performing financing (NPF) is a variable that reflects positive or negative losses in the financing segment. This variable consists of non-accrual loans that are 180 days or more past due on principle of payment (IFSB, 2005). It also measures bank's credit risk as part of capital management (Md. Ramli et al., 2012). Beatty et al. (1995) found a positive relationship between NPL and total loan (TL) and the LLP. In this study, NPF is used as a control variable which indicates an increase in reserve of default payment with increase in NPFs. The size (SIZE) and age (AGE) of the banks are variables used to explain the influence of banks-specific factor while gross domestic product (GDP) is the variable used to capture the macroeconomic effects.

\section{Estimation Method and Regression Equation Models}

This study is based on panel data that are used more commonly in economic and financial analyses. This study employs generalized least square (GLS) to examine the relationship between profit distribution management to depositors and earnings management and capital management. To examine whether managers of Islamic banks use distribution of depositors' return to smooth income, the following regression (Model 1) is set up:

\section{Basic Model:}

Model 1 Earnings management and capital management (H1a, H2a):

$D D R=f\{$ Earnings Management, Capital Management,Non-Performing Financing,Bank Size,Bank Age, and GDP\}

$D D R=f\{E B T Z P, T C B P, N P F, S I Z E, A G E, G D P\}$

Model 1 Earnings management and capital management (H1a, H2a): 
$\operatorname{DDR}_{\mathrm{it}}=\beta_{0}+\beta_{1} E B T Z P_{\mathrm{it}}+\beta_{2} T C B P i t+\beta_{3} N P F_{\mathrm{it}}+$ $\beta_{4} S I Z E_{\mathrm{it}}+\beta_{5} A G E_{\mathrm{it}}+\beta_{6} G D P_{\mathrm{it}}+\varepsilon i t$

Where;

\begin{tabular}{|c|c|c|}
\hline $\mathrm{DDR}_{\mathrm{it}}$ & $=$ & $\begin{array}{l}\text { Asset spread of bank } \mathrm{i} \text { in } \\
\text { year } \mathrm{t} \text { normalized by total } \\
\text { assets }\end{array}$ \\
\hline EBTZP $_{\text {it }}$ & $=$ & $\begin{array}{l}\text { the ratio of earnings } \\
\text { before tax and zakat and } \\
\text { provision of bank } \mathrm{i} \text { in year } \mathrm{t} \\
\text { normalized by total assets }\end{array}$ \\
\hline $\mathrm{TCBP}_{i t}$ & $=$ & $\begin{array}{l}\text { the ratio of total capital } \\
\text { before provision of bank } \mathrm{i} \\
\text { in year t normalized by total } \\
\text { assets }\end{array}$ \\
\hline $\mathrm{NPF}_{\text {it }}$ & $=$ & $\begin{array}{l}\text { the ratio of non-performing } \\
\text { financing of bank } i \text { in year } t \\
\text { normalized by total assets }\end{array}$ \\
\hline $\mathrm{SIZE}_{\mathrm{it}}$ & $=$ & logarithm of total assets \\
\hline $\mathrm{AGE}_{\mathrm{it}}$ & $=$ & $\begin{array}{l}\text { number of years of the } \\
\text { respective Islamic bank } \\
\text { operation }\end{array}$ \\
\hline $\mathrm{GDP}_{\text {it }}$ & $=$ & $\begin{array}{l}\text { the rate of growth of gross } \\
\text { domestic product in year } t\end{array}$ \\
\hline & & error term \\
\hline
\end{tabular}

Model 2 employs an asymmetric pattern of distribution of depositors' return during periods of positive (good) and negative (bad) earnings. In this model, the variable representing earnings management interacts with the dummy variable which takes the value of 1 when the earnings are negative and zero otherwise (EBTZP*DEM). The expected sign of this variable is positive. Md. Ramli et al. (2012) found the relationship between EBTZP*DEM and PER in his model to be positive. The model is written as follows.

Model 2 Earnings management with interactive dummy negative earnings (H1b):

$D D R=f$ \{earnings management with dummy variable,capital management\}

$D D R_{i t}=\beta_{0}+\beta_{1} E B T Z P_{i t} * D_{E M}+\beta_{2} T C B P_{i t}+\beta_{3} N$ $P F_{i t}+\beta_{4} S I Z E_{i t}+\beta_{5} A G E_{i t}+\beta_{6} G D P_{i t}+\varepsilon_{i t}$
The variable TCBP is allowed to interact with a dummy variable to examine capital management behaviour for banks with loan loss reserves ratio. It takes the value of 1 for DCM if the reserve ratio exceeds $1.25 \%$ rate and zero otherwise. The dummy helps in studying the effects of the pattern of capital cycle (Md. Ramli et al., 2012). It is assumed that if a bank does not limit the ratio of loan loss reserves and practices forward-looking provisions then the characteristics of pro-cyclical capital could be reduced. Hence, the existing model equation is rewritten as follows, given the definition and expected signs of all variables in Table 2;

Model 3 Capital management with interactive dummy loan loss reserves $(\mathrm{H} 2 \mathrm{~b})$ :

$D D R=f$ \{earnings management with dummy variable,capital management with dummy variable\}

$D D R_{i t}=\beta_{0}+\beta_{1} E B T Z P_{i t} * D_{E}+\beta_{2} T C B P_{i t} * D_{C}+\beta_{3} N$
$P F_{i t}+\beta_{4} S I Z E_{i t}+\beta_{5} A G E_{i t}+\beta_{6} G D P_{i t}+\varepsilon_{i t}$

Table 2: Definitions for all variables used in the study

\begin{tabular}{|c|c|c|c|}
\hline Variables & Measurement & $\begin{array}{l}\text { Predicted } \\
\text { Sign }\end{array}$ & Tests \\
\hline $\begin{array}{l}\text { Distribution } \\
\text { of depositors' } \\
\text { return (DDR) }\end{array}$ & $\begin{array}{l}\text { Asset spread= } \\
\text { ROA-ROIAH }\end{array}$ & & $\begin{array}{l}\text { Dependent } \\
\text { variable }\end{array}$ \\
\hline $\begin{array}{l}\text { Earnings } \\
\text { Management } \\
\text { (EBTZP) } \\
(\text { EBTZP*DEM) }\end{array}$ & $\begin{array}{l}\text { Profit before } \\
\text { tax, zakat and } \\
\text { provision/Total } \\
\text { assets } \\
\text { Unity if earnings } \\
\text { are negative and } \\
\text { zero otherwise. }\end{array}$ & $(+)$ & $\begin{array}{l}\text { To test } \\
\text { whether the } \\
\text { banks make } \\
\text { significantly } \\
\text { higher } \\
\text { provision } \\
\text { when they } \\
\text { incur losses } \\
\text { than when } \\
\text { they are not. }\end{array}$ \\
\hline $\begin{array}{l}\text { Capital } \\
\text { Management } \\
(\mathrm{TCBP}) \\
(\mathrm{TCBP} * \mathrm{DCM})\end{array}$ & $\begin{array}{l}\text { Total capital } \\
\text { before provision } \\
\text { (Tier } 1 \text { )/Total } \\
\text { assets } \\
\text { Unity if loan loss } \\
\text { reserve is more } \\
\text { than } 1.25 \% \text { and } 0 \\
\text { otherwise }\end{array}$ & $\begin{array}{l}(-) \\
(+/-)\end{array}$ & $\begin{array}{l}\text { To test } \\
\text { whether there } \\
\text { is strong } \\
\text { support for } \\
\text { the capital } \\
\text { management } \\
\text { hypothesis. }\end{array}$ \\
\hline $\begin{array}{l}\text { Non-performing } \\
\text { financing } \\
(\mathrm{NPF})\end{array}$ & $\begin{array}{l}\text { Non-performing } \\
\text { financing }\end{array}$ & $(+)$ & Control \\
\hline
\end{tabular}




\begin{tabular}{|c|c|c|c|}
\hline $\begin{array}{l}\text { Bank size } \\
\text { (SIZE) }\end{array}$ & Log (total assets) & $(+)$ & Control \\
\hline Bank age (AGE) & $\begin{array}{l}\text { Number of } \\
\text { years of bank } \\
\text { operation or } \\
\text { dummy variable } \\
\text { that equals } 1 \text { for } \\
\text { banks that have } \\
\text { been established } 4 \\
\text { years prior to year } \\
t \text { and } 0 \text { otherwise. }\end{array}$ & $(-)$ & Control \\
\hline $\begin{array}{l}\text { Gross domestic } \\
\text { product growth } \\
\text { (GDP) }\end{array}$ & $\begin{array}{l}\text { The rate of gross } \\
\text { domestic product } \\
\text { growth }\end{array}$ & $(-)$ & Control \\
\hline
\end{tabular}

Adopted and modified from Ismail and Shahimi (2006), Md. Ramli et al. (2012) and Farook et al. (2012).

\section{Results \& Discussion}

\section{Descriptive Statistic}

The statistical analysis of the sample data was done using E-Views 7 software. Table 2 gives a summary of the dependent and independent variables employed in the panel data analysis. The DDR value of -0.0389 suggests that from 2008 to 2012, Islamic banks in Malaysia have an average of $-3.89 \%$ Asset Spread, indicating a very low distribution of depositors' return. This implies that Islamic banks in Malaysia provide economic returns, rather than manage returns. This is quite similar to findings recorded by Farook et al. (2012), whereby the Asset
Spread for his Malaysian sample was $1.8 \%$. It is also consistent with findings by Md. Ramli et al. (2012), Zoubi and Al-Khazali (2007), and Taktak et al. (2010), with low PER and LLPs.

The mean, median, and standard deviation for EBTZP to total assets are $0.7 \%, 0.84 \%$, and $1.12 \%$ respectively (Table 3 ). TCBP is measured by the ratio of Tier I capital to the total assets. The mean, median, and standard deviation of TCBP are $9.07 \%, 7.65 \%$, and $5.39 \%$ respectively. The mean for NPF to total assets in this study is about $1.46 \%$. For natural logarithm of total assets, it reports $7.22 \%$ on average and $0.64 \%$ on standard deviation whilst the growth of GDP reports $4.22 \%$ on average. Also reported in Table 2 are some statistical properties of the panel data, including the skewness and normality tests. With regards to the panel data distribution, results suggest that most data tend to be skewed both positively and negatively. The distributions are also fat-tailed (kurtosis $>3.00$ ) particularly in cases of DDR, EBTZP, TCBP, and NPF. The data sample is considered normally distributed if the value of skewness is close to zero. The resulting Jarque-Bera values are all significant $(p<0.01)$, suggesting that none of the data is normally distributed. Such violation of normally distributed data nonetheless is common when financial data is concerned (Mulyo, 2012).

Table 3: Summary of descriptive statistics for the overall sample data

\begin{tabular}{|c|c|c|c|c|c|c|c|c|}
\hline Variables & Mean & Median & $\begin{array}{l}\text { Std. } \\
\text { Dev. }\end{array}$ & Skewness & Kurtosis & Maximum & Minimum & Jarque-Bera \\
\hline DDR & -0.0389 & -0.0562 & 0.3227 & 1.2187 & 7.8464 & 1.5789 & -0.9586 & $\begin{array}{c}196.2291 \\
(0.0000 * * *)\end{array}$ \\
\hline EBTZP & 0.0074 & 0.0084 & 0.0112 & -4.8723 & 34.2765 & 0.0232 & -0.0735 & $\begin{array}{c}3738.84 \\
(0.0000 * * *)\end{array}$ \\
\hline TCBP & 0.0907 & 0.0765 & 0.0539 & 2.3780 & 8.3990 & 0.3695 & 0.0253 & $\begin{array}{c}275.8567 \\
(0.0000 * * *)\end{array}$ \\
\hline NPF & 0.0146 & 0.0074 & 0.0226 & 3.8264 & 17.4634 & 0.1473 & 0.0000 & $\begin{array}{c}1075.394 \\
(0.0000 * * *)\end{array}$ \\
\hline SIZE & 7.2192 & 7.0565 & 0.6370 & 2.2564 & 5.5137 & 9.3877 & 6.4914 & $\begin{array}{c}152.0828 \\
(0.0000 * * *)\end{array}$ \\
\hline AGE & 0.5375 & 1.0000 & 0.5017 & -0.1533 & -2.0278 & 1.0000 & 0.0000 & $\begin{array}{c}13.3350 \\
(0.0013 * * *)\end{array}$ \\
\hline GDP & 4.2200 & 5.1000 & 3.0446 & -1.2304 & 0.0121 & 7.2000 & -1.6000 & $\begin{array}{c}19.4459 \\
(0.0001 * * *)\end{array}$ \\
\hline
\end{tabular}

Note: $* * *$ All Jarque-Bera statistics are significant at $1 \%$ level. In all cases, $\mathrm{N}=80$ observations 
Table 4 shows the correlation analysis of the variables used in this study. The correlation between DDR and independent variables (TCBP, SIZE, AGE, and GDP) are negative except for EBTZP and NPF. The correlation coefficients between these variables are low (correlation $<0.8$ ), suggesting an absence of multicollinearity problems (Gujarati and Porter, 2009). Md. Ramli et al. (2012) found that the correlations between PER and bank size (SIZE) and PER and GDP growth are both positive whilst PER and variables like earnings before tax, zakat, and provision (EBTZP), total capital before provision (TCABP), and NPF are all negative. In this study, the negative correlation between DDR and NPF suggests the lack of or minimal dynamic provision being exercised by bank operators whilst the negative correlation of EBTZP suggests a lack of income smoothing practice (Taktak et al., 2010; Md. Ramli et al., 2012).
However, capital management was found to have a significant effect on distribution of depositors' return with the p-value being significant at 1 percent level $(p=0.0000)$. The positive sign of TCBP ratio is consistent with our expectation indicating that the higher the capital ratio, the higher the distribution of depositors' return. Hence, the hypothesis $H 2 a$ that suggests capital management has a significant effect on distribution of depositors' return is accepted. It indicates that banks with lower capital boost their capital by reducing distribution to depositors. Taktak et al. (2010) and Md. Ramli et al. (2012) have suggested similar result regarding capital management.

The second objective of the study is to examine the extent, earnings management is associated with distribution of depositors' return.

Table 4: Correlation analysis among variables

\begin{tabular}{|l|l|l|l|l|l|l|l|}
\hline & DDR & EBTZP & TCBP & NPF & SIZE & AGE & GDP \\
\hline DDR & 1.0000 & & & & & \\
\hline TCBTZP & $-0.0536^{*}$ & 1.0000 & & & & \\
\hline NPF & $0.023^{* *}$ & -0.238 & 1.0000 & & & \\
\hline SIZE & -0.1666 & -0.635 & 0.358 & 1.0000 & & \\
\hline AGE & 0.1602 & $-0.0679 *$ & 0.232 & $-0.0266^{* *}$ & 1.0000 & \\
\hline GDP & 0.1330 & -0.1413 & -0.1295 & 0.2047 & 0.265 & 1.0000 & \\
\hline
\end{tabular}

Notes:* Correlation is significant at 0.1 level (2-tailed); **

Correlation is significant at 0.05 level (2-tailed)

\section{Finding Analysis}

Consistent with the findings documented by Ismail and Shaharudin (2003), Zoubi and AlKhazali (2007), Taktak et al. (2010), and Md. Ramli et al. (2012), regression results of Model 1 in Table 4 show that there is insignificant effect between earnings management and distribution of depositors' return. Thus, the result rejects the H1a hypothesis that states that the Malaysian Islamic banks are intervening distribution of depositors' return when managing their earnings, thereby, refuting the notion that income smoothing is done via distribution of depositors' return.
In Table 4, the results of EBTZP*DEM in Model 2 are significant, inconsistent with the finding by Md. Ramli et al. (2012), which reported insignificant correlation between earnings management with interactive negative earnings on PER. Our result supports $H 1 b$ hypothesis that earnings management with dummy negative earnings has positive and significant relationship with distribution of depositors' return $(p=0.0018)$. This means that the ways banks manage their distribution of depositors' return when earnings are negative are by maintaining capital (deposits) and maintaining returns to depositors at an agreeable ratio. 
Table 5: Regression results using GLS with dependent variable of DDR

\begin{tabular}{|c|c|c|c|}
\hline & \multicolumn{3}{|c|}{$\begin{array}{l}\text { Dependent variable }=\text { DDR } \\
\text { (Asset Spread) }\end{array}$} \\
\hline & Model 1 & Model 2 & Model 3 \\
\hline Variables & Direct effect & $\begin{array}{l}\text { Integrative dummy } \\
\text { earnings negative (DEM) }\end{array}$ & $\begin{array}{l}\text { Integrative dummy earnings negative (DEM) } \\
\text { and dummy loan loss reserves }>1.25 \text { (DCM) }\end{array}$ \\
\hline CONSTANT & 0.4581 & 0.7803 & 0.5836 \\
\hline \multicolumn{4}{|l|}{ Earnings management } \\
\hline EBTZP & 0.1283 & 0.5003 & 0.6893 \\
\hline EBTZP*DEM & - & $0.0018 * * *$ & $0.0056^{* * * *}$ \\
\hline \multicolumn{4}{|l|}{ Capital management } \\
\hline TCBP & $0.0000 * * *$ & $0.0000 * * *$ & $0.0000^{* * *}$ \\
\hline TCBP*DCM & - & - & 0.2849 \\
\hline \multicolumn{4}{|l|}{ Control variables } \\
\hline NPF & $0.0002 * * *$ & $0.0003 * * *$ & $0.0003 * * *$ \\
\hline SIZE & 0.9904 & 0.616 & 0.7069 \\
\hline AGE & $0.0036^{* * *}$ & $0.0019 * * *$ & $0.005 * * *$ \\
\hline GDP & 0.5409 & 0.5536 & 0.5121 \\
\hline $\mathrm{R}^{2}$ & 0.5238 & 0.5260 & 0.4513 \\
\hline Adjusted $\mathrm{R}^{2}$ & 0.3313 & 0.3278 & 0.2980 \\
\hline F-statistic & 7.5238 & 6.5040 & 5.1909 \\
\hline Prob (F-statistic) & 0.0000 & 0.0000 & 0.0000 \\
\hline Durbin-Watson stat & 2.0796 & 2.0098 & 2.0046 \\
\hline
\end{tabular}

Note: $* * *$ denotes $1 \%$ significance level.

With regards to capital management with dummy loan loss reserves and distribution of depositors' return, the results of Model 3 , as depicted in Table 5 shows that capital management (TCBP*DCM) has an insignificant relationship with distribution of depositors' return ( $\mathrm{p}=0.2849)$, thus, rejects the $H 2 b$ hypothesis. This contradicts that of Taktak et al. (2010) and Md. Ramli et al. (2012), which had significant negative results on TCBP. Our result implies that the various pattern of capital cycle provides no effect whatsoever on the distribution return of Malaysian Islamic banks. Misman and Ahmad (2011) showed a very different result with regards to capital management of conventional banks and Islamic banks in relation to LLP. They found a negative correlation for conventional banks but a positive one with Islamic banks. Collectively, these results provide strong support for capital management as income smoothing instrument.
The results of this study are important in assessing banks' financial stability as well as depositors' confidence. Our findings are significant for capital management but insignificant for earnings management. This brings to a conclusion that Malaysian Islamic banks manage their distribution of depositors' return using capital management. There are studies done by Sundararajan (2005) and Farook et al., (2012) on profit distribution but none of them were tested in the presence of earnings management except those by Faouzi and Zarai (2013).

Based on the findings of asymmetric pattern of distribution of depositors' return during periods of positive (good) and negative (bad) earnings, Malaysian Islamic banks manage their earnings through distribution of depositors' return when earnings are negative. This are done to avoid earnings fluctuations, at the same time reduces panic that could have led to bank runs. 
Most importantly, our findings add substantial evidence to the scant existing literature on the current rate of return risk. We discovered that the practice of income smoothing through capital management allows for meeting the depositors' expected return. Secondly, it emphasizes the importance of adopting strict distribution of profit methodologies in the banking industry. An advantage of the distribution return pays out to depositors is it manages to tackle the issues of earnings deterioration and rate of return risk. The findings are consistent with two aspects of income smoothing practices which are earnings management and capital management, and have the potential to extend towards smoothing returns to depositors via profit distribution as proposed by Farook et al. (2012).

\section{Conclusion}

As a conclusion, the evidence gathered suggests that most Islamic banks in Malaysia manage distribution of depositors' return for the purpose of income smoothing. They practice this with prudence and on their own initiative in an effort to mitigate withdrawal risk and displaced commercial risk during bad earnings. These results may have potential literature and policy implications on regulators of Islamic banks in association with the rate of return framework. It discovers that the practice of profit distribution may implicitly have flexibility to meet the depositors' expected return. Secondly, it gives and implication of the importance of adopting stricter distribution of profit methodologies in banking industry. An advantage of the distribution return pays out to depositors is it manages to tackle the issues of earnings deterioration and rate of return risk. Further research should focus on other potential determinants affecting distribution of depositors' return in Islamic banks. In addition, the issue of distribution of depositors' return should also be examined on other type of IFIs offering Islamic financial products and services in Malaysia i.e. development banks such as Agro bank, SME Bank, Bank Simpanan Nasional and
Bank Rakyat cooperative bank.

\section{References}

AAOIFI. (1999). Accounting, Auditing and Governance Standards for the Islamic Financial Institutions.

Abdeljawad, I., Nor, F. M., \& Ibrahim, I. (2012). Heterogeneous adjustments toward the target capital structure: Dynamic tradeoff theory Perspective. Proceeding of the 14th MFA Conference 2012.

Ab-Rahim, R. \& Chiang, S.N. (2016). Market structure and performance of Malaysian banking industry. Journal of Financial Reporting and Accounting, 14(2), 1-16.

Ahmed, A. S., Takeda, C., \& Thomas, S. (1999). Bank loan loss provisions : a reexamination of capital management, earnings management and signaling effects. Journal of Accounting and Economics, 28(1).

Ahmed, E. T. A. (1996). Distribution of profits in Islamic banking: A case study of Faysal Islamic bank of Sudan (FIBS). J.KAU: Islamic Econ, 8, 15-32.

Anandarajan, A., Hasan, I., \& Lozano-Vivas, A. (2003). The role of loan loss provisions in earnings management, capital management, and signaling: The Spanish experience. Advances in International Accounting, 16(03), 45-65.

Anandarajan, A., Hasan, I., \& McCarthy, C. (2006). The use of loan loss provisions for capital management, earnings management and signalling by Australian banks. Discussion Paper, 23, Bank of Finland Research.

Ashour, M.O. (2011). Banks loan loss provisions role in earnings and capital management: Evidence from Palestine. Master Thesis in Accounting \& Finance, Islamic University Gaza. 
Bank Negara Melaysia, BNM. (2012, March 11). List of Licensed Banking Institutions in Malaysia - Islamic Banks. Retrieved March 11, 2012 from http://www.bnm.gov.my/index.php $? \mathrm{ch}=$ li\&cat $=$ islamic $\&$ type $=\mathrm{IB} \&$ fund $=0 \& \mathrm{cu}=0$.

Barnea, A., Ronen, J. \& Sadan, S. (1976). Classificatory smoothing of income with extraordinary items. The Accounting Review, 56(1), 110-22.

Beatty, Chamberlain, S.L. \& Magliolo, J. (1995). Managing financial reports of commercial banks: Influences of taxes, regulatory capital and earnings. Journal of Accounting Research, $33(2), 231-262$.

Chattha, J.A. \& Archer, S. (2016). Solvency stress testing of Islamic commercial banks: Assessing the stability and resilience. Journal of Islamic Accounting and Business Research, 7(2), 112-147.

Cheng, Q., Warfield, T., \& Ye, M. (2011). Equity incentives and earnings management: evidence from the banking industry. Journal of Accounting, Auditing \& Finance, 26(2), 317349.

Chong, B.S. \& Liu, M.H. (2009). Islamic banking: Interest free or interest based. Pacific Basin Finance Journal, 17, 125-144.

Faouzi, H. M., \& Zarai, M. A. (2013). Earnings management and investment accounts holders interests in Islamic banking institutions. International Journal of Business and Management Invention, 2(12), 22-35.

Farook, S. Z., \& Farooq, M. O. (2011). Incentivebased regulation for Islamic banks. Journal of Islamic Accounting and Business Research, 2(1), 8-21.
Farook, S., Hassan, M. K., \& Clinch, G. (2012). Profit distribution management by Islamic banks: An empirical investigation. The Quarterly Review of Economics and Finance, 52(3), 333347. Board of Trustees of the University of Illinois.

Fonseca, A. R., \& González, F. (2007). Crosscountry determinants of bank income smoothing by managing loan-loss provisions. Journal of Banking \& Finance, 32(2), 217-228.

Gujarati, D \& Porter, D.C. (2009). Basic Econometrics, 5th ed., McGraw-Hill, New York, NY.

Hamza, H. \& Saadaoui, Z. (2013). "Investment deposits, risk-taking and capital decisions in Islamic banks". Studies in Economics and Finance, 30(3), 244-265.

Hamza, H. \& Saadaoui, Z. (2013). Investment deposits, risk $\square$ taking and capital decisions in Islamic banks. Studies in Economics and Finance, 30(3), 244-265.

Haneef, R. (2015). "Has Islamic finance bridged the disconnect with the real economy?" 5th ISRA-IRTI-Durham University Strategic Roundtable Discussion (SRD) 2015.

IFSB. (2005). Guiding Principles of Risk Management for Institutions (other than Insurance Institutions) Offering Only Islamic Financial Services, IFSB, Kuala Lumpur.

Islamic Financial Services Industry Stability Report 2015. Published by Islamic Financial Services Board (IFSB), Bank Negara Malaysia, Kuala Lumpur. May 2015.

Ismail, A. G. \& Shaharuddin, R. S., (2003). Earnings management behavior by Islamic banking managers. Indonesian Management \& Accounting Research, 2(2), 111-126. 
Ismail, A. G. (2010). Money, Islamic Banks, and the Real Economy, Cengage Learning Asia Pte Ltd.

Ismail, A. G., \& Be Lay, A. T. (2002). Bank loans portfolio composition and the disclosure of loan loss provision: An empirical evidence of Malaysian banks. Asian Review of Accounting, 10(1), 147-162.

Ismail, A. G., Shaharudin, R. S., \& Samudhram, A. R. (2005). Do Malaysian banks manage earnings through loan loss provisions? Journal of Financial Reporting and Accounting 1(3), 41-47.

Ismail, A.G. \& Shahimi, S. (2006). Profit equalization reserve decisions: an empirical analysis of Islamic banks in Malaysia. Working Paper in Islamic Economics and Finance No. 0605, available at: www.pkukmweb.ukm.my/ ekonis/2006/wpief0605_per.pdf

ISRA. (2012). Islamic Financial System: Principles and Operations, Perpustakaan Negara Malaysia.

Lahrech, N., Lahrech, A. \& Boulaksil, Y. (2014). Transparency and performance in Islamic banking: Implications on profit distribution. International Journal of Islamic and Middle Eastern Finance and Management, 7(1), 61-88.

Md. Ramli, R., Shahimi, S., \& Ismail, A. G. (2012). Do Malaysian Islamic banks manage earnings through profit equalization reserve? Proceeding of the 14th MFA Conference 2012.

Mersni, H. \& Othman, H.B. (2016). The impact of corporate governance mechanisms on earnings management in Islamic banks in the Middle East region. Journal of Islamic Accounting and Business Research, 7(4), 1-32.

Misman, F. N., \& Ahmad, W. (2011). Loan loss provisions: evidence from Malaysian Islamic and conventional banks. International Review of Business Research Papers, 7(4), 94-103.
Mokni, R.B.S., Echchabi, A., Azouzi, D. \& Rachdi, H. (2014). Risk management tools practiced in Islamic banks: Evidence in MENA region. Journal of Islamic Accounting and Business Research, 5(1), 77-97.

Mulyo, G. P. (2012). Faktor-faktor yang mempengaruhi profit distribution management atas simpanan deposan pada bank Syariah di Indonesia periode 2008-2011. Skripsi Sarjana Fakultas Ekonomika dan Bisnis Universitas Diponegoro, Semarang, 27-50.

Olson, D. \& Zoubi, T.A. (2014). The determinants of loan loss and allowances for MENA banks: Simultaneous equation and threestage approaches. Journal of Islamic Accounting and Business Research, 5(1), 98-120.

Othman, H.B. \& Mersni, H. (2014). The use of discretionary loan loss provisions by Islamic banks and conventional banks in the Middle East region: A comparative study. Studies in Economics and Finance, 31(1), 106-128.

Sundararajan, V. (2005). Risk measurement and disclosure in Islamic finance and the implications of profit sharing investment accounts, paper presented at Sixth International Conference on Islamic Economics, Banking and Finance, Jakarta, November 22-24.

Sundararajan, V. (2008). Issues in managing profit equalization reserves and investment risk reserves in Islamic banks. Journal of Islamic Economics, Banking and Finance, 1-12.

Taktak, N. B. (2011). The nature of smoothing returns practices: The case of Islamic banks. Journal of Islamic Accounting and Business Research, 2(2), 142-152.

Taktak, N. B., Zouari, S.B.S. \& Boudriga, A. (2010). Do Islamic banks use loan loss provisions to smooth their results? Journal of Islamic Accounting and Business Research, $1(2), 114-127$. 
Wahlen, J.M. (1994). The nature of information in commercial bank loan loss disclosures. The Accounting Review, 69(3), 455-478.

World Islamic Banking Competitiveness Report 2013-14. Retrieved on 12th July, 2013 from http://www.mifc.com/index.php?ch=28\&pg= $72 \& a c=58 \& b b=$ uploadpdf

World Islamic Banking Competitiveness Report 2014-15.

Zoubi, T. A. \& Al-Khazali, O. (2007). Empirical testing of the loss provisions of banks in the GCC region. Managerial Finance, 33(7), 500511.

Zunaidah Sulong, Z. (2015), "Towards Maqasid Al-Shariah Driven: Should Islamic Finance Propogate Innovation and ESG (Environmental, Social and Governance) Issues?" Buletin UniSZA, August 2015, No. 16. ISSN 2180-0235. 
